\title{
Constraints and Suggestions Expressed by Head Reach and Tail-End Farmers for Participation in Effective Canal Irrigation Management
}

\author{
Akkamahadevi Naik*, M. Shivamurthy and N. S. Shivalinge Gowda \\ Department of Agricultural Extension, University of Agricultural Sciences, \\ GKVK, Bengaluru- 560065, India \\ *Corresponding author
}

\section{A B S T R A C T}

\section{Keywords \\ Constraints, \\ Suggestions, \\ Farmers' \\ participation, Canal \\ irrigation \\ management}

\section{Article Info}

Accepted:

10 October 2019

Available Online:

10 November 2019
Present study was conducted in Krishna Command Area at Vijayapura, Kalaburagi and Yadgiri districts of Karnataka to identify the constraints and suggestions expressed by the head reach and tail-end farmers for participation in effective canal irrigation management. Data was collected through personal interview method from eight Water Users Cooperative Societies (WUCS) farmers. Results indicated that, major constraints expressed by the head reach farmers were inadequate training programmes conducted by WUCS, lack of knowledge on integrated crop management, lack of adequate fund from Govt. to improve irrigation structure and groupism and political interference. Similarly the major constraints expressed by the tail-end farmers viz., lack of cooperation and support from irrigation department, obstruction to water flow from upper reach, lack of adequate fund from Govt. to improve irrigation structure and groupism and political interference. These constraints can be overcome by implementing the suggestions as expressed by the head reach farmers like; conduct adequate training programmes on water management, providing information on integrated crop management practices, providing adequate fund from Govt. to improve irrigation structure and participation of farmers for conserving water. Similarly the suggestions expressed by the tail-end farmers were proper cooperation and support from irrigation department, coordination/understanding among the farmers to share water, providing adequate funds from Govt. to improve irrigation structure and giving equal importance given to all members of WUCS.

\section{Introduction}

Rain fall is considered as one of the most supreme source of water, if it is timely and adequately received. But rainfall pattern in India is erratic, varies in different regions, irregular and prominently seasonal. Rainfall extremities in India badly affect the agriculture. The uncertain nature of rainfall in India makes it essential to provide an insurance against crop failure through assured irrigation facilities, thus irrigation plays a crucial role in maintaining the food security in India. Out of the total area under irrigation, 40 per cent area irrigated by canals, 40 per cent by wells or tube wells and 12 per cent by tanks 
and the rest 8 per cent of land are irrigated by other methods (Anon., 2017). Further, 25-30 per cent of water can be saved without reducing the yield by adopting efficient water management practices. But, it often happens that the water available in the command areas is prone to mismanagement at farm level. This is primarily due to the lack of knowledge of farmers on the exact water requirements \& appropriate irrigation schedules and the availability of water in the canal is unequally shared among the farmers. The farmers at the head reach, because of their locational advantage use more irrigation water than their share. Consequently farmer at the tail-end location are deprived of their due share. This eventually leads to conflict among the farmers and there is a widening gap exists between the head reach and tail-end farmers. Thus filling the gap between these two is an emerging challenge in command areas. Efforts have been made to organize farmers in groups like Water Users Associations (WUAs). So that farmers themselves can solve their problems related to water sharing, repairing of field channels and collection of water taxes etc. Keeping these issues, the present study was conducted to identify the constraints and suggestions expressed by the farmers for effective water management.

\section{Materials and Methods}

The study was conducted in Vijayapura, Kalaburagi and Yadgiri, districts of Karnataka state, these districts were purposively selected, since these three districts have maximum net irrigated area and irrigated by Narayanpur Left Bank Canal (NLBC) in Krishna Command Area. Narayanpur Left Bank Canal consisting of five branch canals, however for the purpose of the study, two branches viz., Shahapur Branch Canal and Indi Branch Canal were purposively selected, since these two branches comprise of maximum number of Water User Cooperative Societies under NLBC.
Based on the longest length, two distributories viz., Shahapur Branch Canal (SBC D-6, 36km) and another one from Indi Branch Canal (IBC D-11, 39.38km) were purposively selected. Thus, from Distributory-6, Bommanalli, Wandurga, Chandlapur and Hemnur WUCS were randomly selected, and from Distributory-11, Kakkalmeli, Kulekumatagi, Belur and Ankalaga WUCS were selected. From each WUCS, 25 farmers were selected for the study. Thus, from each distributory i.e., from IBC D-11, 50 farmers from head reach and 50 tail-end farmers were selected. Similarly, from SBC D-6, 50 head reach and 50 tail-end farmers were selected for the study. Thus, the total sample constitutes 200 farmers (i.e., 100 head reach and 100 tail-end farmers). The details of the number of WUCS and farmers selected for the study are presented in Table 1.

\section{Results and Discussion}

The farmers were asked to state the constraints which they faced for participation in effective canal irrigation management. The constraints expressed by the head reach and tail-end farmers were noted and categorized in four groups namely constraints related to WUCS, water availability and utilization, Govt. policies and other constraints.

Constraints faced by the head reach farmers for participation in effective canal irrigation management

It is observed from Table 2 that, the major constraints faced by the head reach farmers were inadequate training programmes conducted by WUCS which ranks first followed by lack of technical guidance (Rank II), lack of awareness about the functions of WUCS (Rank III), lack of cooperation and support from irrigation department (Rank IV), lack of efforts by the officials to efficient distribution of water (Rank V) and 
incapability of the committee to solve water disputes (Rank VI) were the major constraints related to WUCS. The reason might be that many training programmes conducted by irrigation department, were supply driven rather than demand driven training programmes and officials were not having technical knowledge for operating the irrigation structures.

Similarly constraints related to water availability and utilization like lack of knowledge on integrated crop management practices which stands first followed by growing more water consuming crops (Ranks II), obstruction to water flow from upper lateral farmers (Ranks III), lack of information on releasing water among the users (Ranks IV), lack of cooperation among the farmers to share the water (Ranks V) and poor maintenance of field channel (Ranks VI). Farmers are growing high water consuming crops like paddy and sugarcane and violate to follow the recommended cropping patter and most of the upper lateral farmers keep the barriers to flow the water to their neighboring farmers field.

Lack of adequate fund from Govt. to improve irrigation structure (Rank I) followed by lack of grass root level planning (Rank II), not to follow warabandi schedule (Rank III), high water charges (Rank IV) and lack of transparency in planning and implementation (Rank V) were the major constraints related to Govt. policies.

When distributories and field channels under the repair and maintenance, farmers expect that Govt. has to sanction the fund for maintenance of irrigation structure but officials will expect that farmer has to take care of the repair and maintenance of the field channels and another reason might be that many farmers irrigate the land throughout a day without following warabandi schedule.
Regarding other constraints like groupism and political interference was ranks first, followed by lack of initiation and motivation among the farmers (Rank II), illiteracy of the farmers (Rank III), lack of free time to participate (Rank IV), lack of trust on office bearers (Rank V) and lack of motivation from village leaders (Rank VI). The possible reason might be that based on the back ground of the farmers, dominance and strong political groups in the villages, farmers get more water as compare to other farmers and most of the farmers hesitate to come forward to ask their justice on irrigation water and due to the low literacy level, farmers facing the difficulty to understand the rules and regulation of WUCS.The findings of the study are in conformity with the findings of Mohite et al., (1992).

\section{Constraints faced by the tail-end farmers for participation in effective canal irrigation management}

It is observed from Table 3 that, the major constraints related to WUCS faced by the tailend farmers were lack of cooperation and support from irrigation department stands first rank followed by incapability of the committee to solve water disputes (Rank II), lack of efforts by the officials to efficient distribution the water (Rank III), inadequate training programmes conducted by WUCS (Rank IV), lack of awareness about the functions of WUCS (Rank V) and lack of technical guidance (Rank VI).

The reason might be that office bearers complain on farmers that farmers not come forward to discuss with them regarding water issues and farmers will expect that officers should come and discuss to solve the water dispute, therefore there is lack of understanding/coordination between the higher authority and farmers, many societies were failed to equal distribution of water 
among the farmers for that reason there might be always conflict between farmers.

Constraints related to water availability and utilization viz., obstruction to water flow from upper reach farmers ranks first followed by lack of knowledge on integrated crop management practices (Rank II), lack of information on releasing water among the users (Rank III), poor maintenance of field channel (Rank IV), lack of cooperation among the farmers to share the water (Rank V) and growing more water consuming crops (Rank VI).Most of the upper reach/head reach farmers located first under the irrigation source, thus they utilize more water as compared to tail-end farmers.

Many times farmers were not aware about the information on water releasing date and time and other reason might be that farmers unable to maintain the irrigation structures due to the frequent destruction from users. They had attributed to lack of proper control on irrigation, especially at night time.

The constraints related to Govt. policies were lack of adequate fund from Govt. to improve irrigation structure which ranks first followed by high water charges (Rank II), not following of warabandi schedule (Rank III), lack of grass root level planning were ranked (Rank IV) and lack of transparency in planning and implementation (Rank VI).

This is due to the reason that Govt. not sanctioning fund on time for repair and maintenance of irrigation structure and farmers also expressed that high irrigation charges, in spite of paying water charge equally as the head reach farmers, they were not getting sufficient water and other reason like head reach farmers irrigate his field overnight without following warabandi schedule. The findings of the study are in conformity with the findings ofGumaste et al., (1993), Dhillon and Hansra (1995), Anand et al., (1998), Golyanaik (2008), Umamaheshwara (2009) and Dabhiet al., (2010).

Other constraints expressed by the farmers viz., groupism and political interference stands first rank followed by lack of trust on office bearers (Rank II), lack of initiation and motivation among the farmers (Rank III), lack of free time to participate (Rank IV), illiteracy of the farmers (Rank V) and lack of motivation from village leaders (Rank VI). Due to the high political influence and groupism in the village, many tail-end farmers were not getting the justice to share equal amount of water. Majority of the upper reach farmers use motors and pump sets to draw out more water to their fields. The findings of the study are in conformity with the findings of Dhillon and Hansra (1995), Anand et al., (1998), Singh (2000), Shah (2001) and Umamaheshwara (2009).

\section{Suggestions expressed by the head reach farmers in effective canal irrigation management}

The data from Table 4 observed that suggestions expressed by head reach farmers to overcome the constraints on participation in effective canal irrigation management.

Suggestions related to Water Users Cooperative Societies viz., to provide adequate training programmes on water management which ranks first, followed by provide awareness about the functions of WUCS (Rank II), proper cooperation and support from irrigation department (Rank III), timely provide the technical guidance (Rank IV), committee leader has to take lead to solve water disputes (Rank V) and timely distribution of water (Rank VI). 
Table.1 Selection of water users cooperative societies and respondents for the study

\begin{tabular}{|c|c|c|c|c|c|}
\hline Sl. No. & District & Distributories & Taluk & WUCS & No. of respondents \\
\hline \multirow[t]{4}{*}{1} & \multirow{4}{*}{ Yadgiri } & \multirow[t]{4}{*}{ SBC D-6 } & \multirow[t]{3}{*}{ Sorpur } & Bommanalli & 25 \\
\hline & & & & Chandlapur & 25 \\
\hline & & & & Hemnur & 25 \\
\hline & & & Shahapur & Wandurga & 25 \\
\hline \multirow[t]{2}{*}{2} & \multirow[t]{2}{*}{ Vijayapura } & \multirow[t]{4}{*}{ IBC D-11 } & \multirow[t]{2}{*}{ Sindagi } & Kakkalameli & 25 \\
\hline & & & & Kulekumatagi & 25 \\
\hline \multirow[t]{2}{*}{3} & \multirow[t]{2}{*}{ Kalaburagi } & & \multirow[t]{2}{*}{ Jewargi } & Belur & 25 \\
\hline & & & & Ankalaga & 25 \\
\hline Total & 3 & 2 & 4 & 8 & 200 \\
\hline
\end{tabular}

Table.2 Constraints faced by head reach farmers in effective canal irrigation management in Krishna Command Area

\begin{tabular}{|c|c|c|c|c|c|}
\hline \multirow{3}{*}{$\begin{array}{c} \\
\text { Sl. } \\
\text { No. }\end{array}$} & \multirow{3}{*}{ Constraints } & & & \multicolumn{2}{|c|}{$(\mathrm{n} 1=100)$} \\
\hline & & Always & Somewhat & Never & Rank \\
\hline & & $\mathbf{f}(\%)$ & $\mathbf{f}(\%)$ & $\mathbf{f}(\%)$ & \\
\hline \multicolumn{6}{|c|}{ I. Related to WUCS } \\
\hline 1 & Lack of technical guidance & 65 & 29 & 6 & II \\
\hline 2 & Inadequate training programmes conducted by WUCS & 77 & 15 & 8 & I \\
\hline 3 & Incapability of the committee to solve water disputes & 26 & 33 & 41 & VI \\
\hline 4 & Lack of cooperation and support from irrigation department & 53 & 32 & 15 & IV \\
\hline 5 & Lack of awareness about the functions of WUCS & 62 & 26 & 12 & III \\
\hline 6 & $\begin{array}{l}\text { Lack of efforts by the officials to efficient distribution of } \\
\text { water }\end{array}$ & 40 & 31 & 29 & V \\
\hline \multicolumn{6}{|c|}{ II. Related to water availability and utilization } \\
\hline 7 & Obstruction to water flow from upper lateral farmers & 53 & 36 & 11 & III \\
\hline 8 & Lack of information on releasing water among the users & 42 & 30 & 28 & IV \\
\hline 9 & Poor maintenance of field channel & 31 & 7 & 62 & VI \\
\hline 10 & Growing more water consuming crops & 59 & 29 & 12 & II \\
\hline 11 & Lack of cooperation among the farmers to share the water & 38 & 33 & 29 & V \\
\hline 12 & $\begin{array}{c}\text { Lack of knowledge on integrated crop management } \\
\text { practices }\end{array}$ & 62 & 29 & 9 & I \\
\hline \multicolumn{6}{|c|}{ III. Related to Govt. policies } \\
\hline 13 & High water charges & 28 & 32 & 40 & IV \\
\hline 14 & Lack of grass root level planning & 48 & 35 & 17 & II \\
\hline 15 & $\begin{array}{l}\text { Lack of adequate fund from Govt. to improve irrigation } \\
\text { structure }\end{array}$ & 52 & 33 & 15 & I \\
\hline 16 & Not following of warabandi schedule & 46 & 41 & 13 & III \\
\hline 17 & Lack of transparency in planning and implementation & 4 & 29 & 67 & V \\
\hline \multicolumn{6}{|c|}{ IV. Other constraints } \\
\hline 19 & Lack of motivation from village leaders & 10 & 37 & 53 & VI \\
\hline 20 & Lack of free time to participate & 36 & 21 & 43 & IV \\
\hline 21 & Groupism and political interference & 56 & 32 & 12 & I \\
\hline 22 & Lack of initiation and motivation among the farmers & 52 & 31 & 17 & II \\
\hline 23 & Illiteracy of the farmers & 48 & 20 & 32 & III \\
\hline 24 & Lack of trust on office bearers & 12 & 32 & 56 & V \\
\hline
\end{tabular}

\section{$* \mathbf{f}=$ frequency}


Table.3 Constraints faced by tail-end farmers in effective canal irrigation management in Krishna Command Area

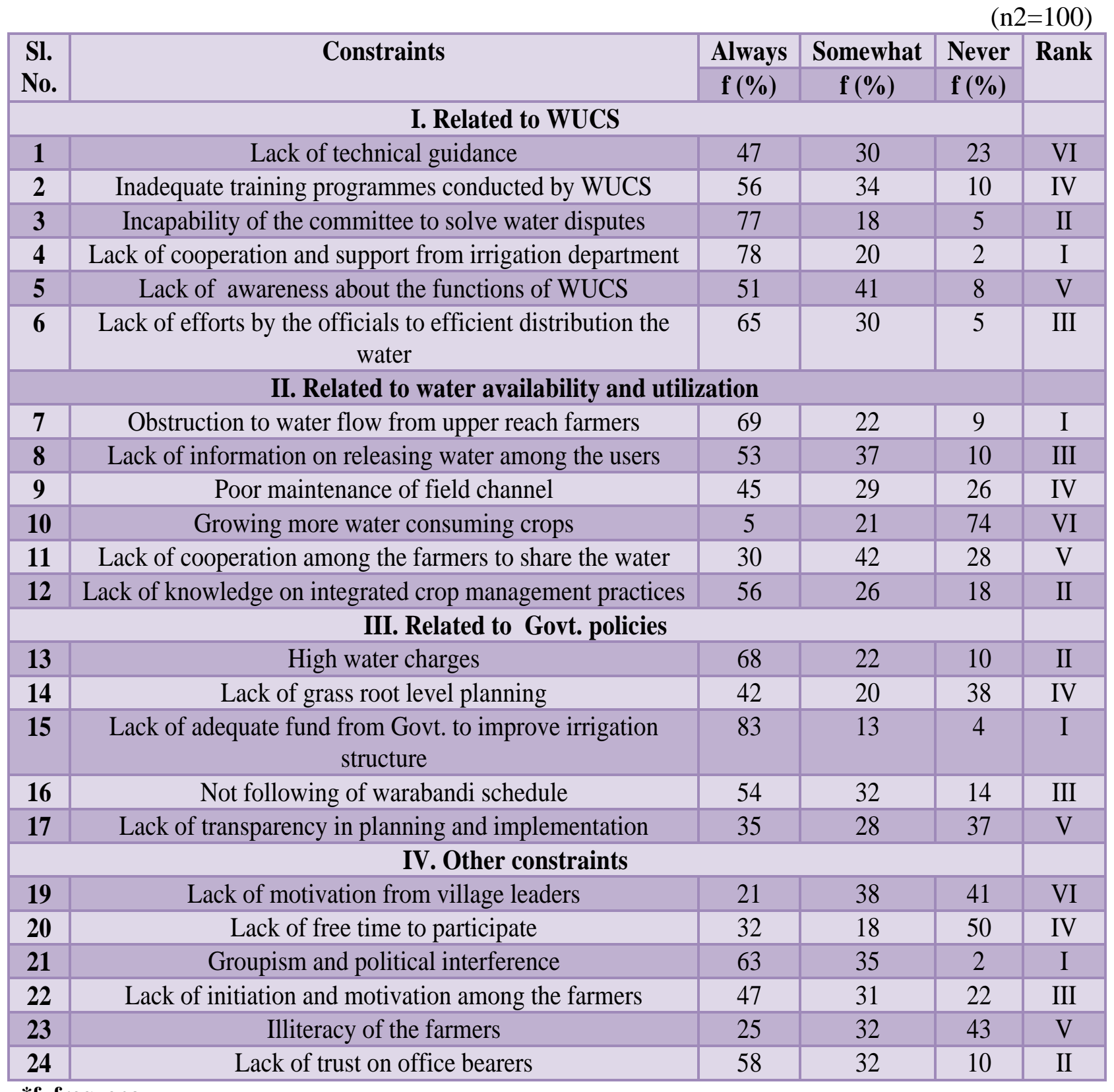

$*$ f $=$ frequency 
Table.4 Suggestions expressed by the head reach farmers in effective canal irrigation management in Krishna Command Area

\begin{tabular}{|c|c|c|c|c|}
\hline \multirow{3}{*}{$\begin{array}{l}\text { Sl. } \\
\text { No. }\end{array}$} & \multirow{3}{*}{ Suggestions } & \multicolumn{3}{|c|}{$(\mathrm{n} 1=100)$} \\
\hline & & Yes & No & \multirow[t]{2}{*}{ Rank } \\
\hline & & $\mathrm{f}(\%)$ & $\mathbf{f}(\%)$ & \\
\hline \multicolumn{5}{|c|}{ I. Related to WUCS } \\
\hline 1 & Timely provide the technical guidance & 56 & 44 & IV \\
\hline 2 & Adequate training programmes on water management & 71 & 29 & I \\
\hline 3 & Committee leader has to take lead to solve water disputes & 51 & 49 & $\mathrm{~V}$ \\
\hline 4 & Proper cooperation and support from irrigation department & 57 & 43 & III \\
\hline 5 & Provide awareness about the functions of WUCS & 69 & 31 & II \\
\hline 6 & Timely distribution of water & 45 & 55 & VI \\
\hline \multicolumn{5}{|c|}{ II. Related to water availability and utilization } \\
\hline 7 & Coordination/understanding among the farmers to share water & 25 & 75 & V \\
\hline 8 & Providing prior information on releasing water & 58 & 42 & III \\
\hline 9 & Proper maintenance of field channel & 34 & 66 & IV \\
\hline 10 & Growing less water consuming crops & 62 & 38 & II \\
\hline 11 & Provide information on integrated crop management practices & 87 & 13 & I \\
\hline \multicolumn{5}{|c|}{ III. Related to Govt. policies } \\
\hline 12 & Minimize water charge & 38 & 62 & $\mathrm{~V}$ \\
\hline 13 & Involve the farmers in planning stage & 72 & 28 & II \\
\hline 14 & Adequate fund from Govt. to improve irrigation structure & 85 & 15 & I \\
\hline 15 & Announcement to strictly follow the warabandi schedule & 64 & 36 & III \\
\hline 16 & Transparency in planning and implementation & 47 & 53 & IV \\
\hline \multicolumn{5}{|c|}{ IV. Other suggestions } \\
\hline 17 & Motivation from the village leaders & 61 & 39 & IV \\
\hline 18 & Participation is require to conserve water & 91 & 9 & I \\
\hline 19 & Equal importance given to all members & 76 & 24 & III \\
\hline 20 & Initiation and motivation from the farmers & 42 & 58 & V \\
\hline 21 & Create awareness and interest on the educational programme & 87 & 13 & II \\
\hline
\end{tabular}


Table.5 Suggestions expressed by the tail-end farmers in effective canal irrigation management in Krishna Command Area

\begin{tabular}{|c|c|c|c|c|}
\hline & & & & $2=100)$ \\
\hline Sl. & Suggestions & Yes & No & Rank \\
\hline No. & & $\mathbf{f}(\%)$ & $\mathbf{f}(\%)$ & \\
\hline & Related to WUCS & & & \\
\hline 1 & Timely provide the technical guidance & 86 & 14 & IV \\
\hline 2 & Adequate training programmes on water management & 91 & 9 & III \\
\hline 3 & Committee leader has to take lead to solve water disputes & 79 & 21 & VI \\
\hline 4 & Proper cooperation and support from irrigation department & 100 & 0 & I \\
\hline 5 & Provide awareness about functions of WUCS & 83 & 17 & V \\
\hline 6 & Timely distribution of water & 93 & 7 & II \\
\hline & Related to water availability and utilization & & & \\
\hline 7 & Coordination/understanding among the farmers to share water & 95 & 5 & I \\
\hline 8 & Providing prior information on releasing water & 76 & 24 & II \\
\hline 9 & Proper maintenance of field channel & 38 & 62 & $\mathrm{~V}$ \\
\hline 10 & Growing less water consuming crops & 47 & 53 & IV \\
\hline 11 & Provide information on integrated crop management practices & 62 & 38 & III \\
\hline & III. Related to Govt. policies & & & \\
\hline 12 & Minimize water charge & 91 & 9 & III \\
\hline 13 & Involve the farmers in planning stage & 80 & 20 & IV \\
\hline 14 & Adequate fund from Govt. to improve irrigation structure & 97 & 3 & I \\
\hline 15 & Announcement to strictly follow the warabandi schedule & 95 & 5 & II \\
\hline 16 & Transparency in planning and implementation & 76 & 24 & $\mathrm{~V}$ \\
\hline & IV. Other suggestions & & & \\
\hline 17 & Motivation from the village leaders & 70 & 30 & IV \\
\hline 18 & Participation is require to conserve water & 76 & 24 & II \\
\hline 19 & Equal importance given to all members & 84 & 16 & I \\
\hline 20 & Initiation and motivation from the farmers & 72 & 28 & III \\
\hline 21 & Create awareness and interest on the educational programme & 65 & 35 & V \\
\hline
\end{tabular}

$* \mathbf{f}=\mathbf{f r e q u e n c y}$

The results indicated that the adequate and need based training programmes and awareness on functions of WUCS help the farmers to take up appropriate measures to conserve irrigation water and timely distribution of water encourage the farmers to 
irrigate their field crop at the critical stage thus farmers may get good yield and income.

Suggestions related to water availability and utilization viz., majority of the farmers expressed to provide information on integrated crop management practices was ranked first followed by growing less water consuming crops (Rank II), providing prior information on releasing water (Rank III), proper maintenance of field channel (Rank IV) and coordination/understanding among the farmers to share water (Rank V).

The results indicated that majority of the farmers lacking knowledge on integrated crop management practices therefore more field visits and demonstrations to be conducted to the farmers, hence farmers can imbibe the knowledge on integrated crop management practices and grow less water consuming crops to save the water and team to supervise and monitor the repair works. The findings of the study are in conformity with the findings of Hasmukh and Lokesh (2016).

With respect to Govt. policies majority of the farmers suggested that adequate fund from Govt. to improve irrigation structure was ranks first followed by involve the farmers in planning stage (Rank II), announcement to strictly follow the warabandi schedule (Rank III), transparency in planning and implementation (Rank IV) and minimize water charge (Rank V). The results indicated that Govt. should sanction the adequate fund on time for repair and maintenance thus farmers involve in cleaning irrigation structure prior to monsoon, hence that helps all the farmers to get water and frequently held the group meetings therefore all the farmers discuss about the planning and implementation activities.

Other suggestion viz., participation is require for conserving water which ranked first followed by create awareness and interest on the educational programme (Rank II), equal importance given to all members (Rank III), motivation from the village leaders (Rank IV) and initiation and motivation from the farmers (Rank V).Conducting exposure visits for the farmers, thus they can learn the other water conservation practices and insist them to go for water saving technologies (drip/sprinkler irrigation method) and also it is necessary to consider all the members/farmers are equal in group for sharing available water.The findings of the study are in conformity with the findings of Mohan and Rameshkumar (2013).

\section{Suggestions expressed by the tail-end farmers in effective canal irrigation management}

The data from Table 5 revealed that suggestions expressed by the tail-end farmers to overcome the problems for participation in effective canal irrigation management.

Tail-end farmers were expressed suggestions related to WUCS viz., proper cooperation and support from irrigation department which ranks first, followed by timely distribution of water (Rank II), adequate training programmes on water management (Rank III), timely provide the technical guidance (Rank IV), provide awareness about the functions of WUCS (Rank V) and committee leader has to take lead to solve water disputes (Rank VI). The results indicated that unequal distribution of water creates conflict among the farmers, therefore committee leader has to take the lead because in villages most of the farmers believe the village leader rather than office bearer. Timely distribution of water helps the tail-end farmers to get good yield. The officials should frequently visit the societies and discuss with farmers and provide awareness on WUCS function, hence the farmers come to know his/her responsibility as a member of WUCS. 
Majority suggestions related to water availability and utilization were proper coordination/understanding among the farmers to share water was ranks first followed by providing prior information on releasing water (Rank II), provide information on integrated crop management practices (Rank III), growing less water consuming crops (Rank IV) and proper maintenance of field channel (Rank V). The results indicated that as discussed in earlier, the tail-end farmers receive less water compared to head reach farmers, therefore based on their mutual understanding the farmers as to share the water, hence everybody can access canal water. Majority of the farmers practicing the mono cropping system, therefore it is necessary to provide information on integrated crop management practices by conducting training programmes.

With respect to Govt. policies majority of the farmers suggested that adequate fund from Govt. to improve irrigation structure stands first followed by announcement to strictly follow the warabandi schedule (Rank II), minimize water charge (Rank III), and involve the farmers in planning stage (Rank IV) and transparency in planning and implementation (Rank V).

The results indicated that adequate supply of fund from the Govt. help the farmers to maintain the field irrigation channels prior to monsoon and one farmer as to irrigate at day time and neighboring farmers irrigate at night time that helps all the farmers to access the irrigation facility and water charges should be collected based on the farmers location and amount of water used.

Other suggestions like equal importance given to all members which ranks first followed by participation is require to conserve water (Rank II), initiation and motivation from the farmers (Rank III), motivation from the village leaders (Rank IV) and create awareness and interest on the educational programme (Rank V). The results indicated that there should not be any discrimination based on their background, hence equal importance to be given to all the member of WUCS and all should come forward and take initiation to conserve the excess water by following appropriate water saving measures. The findings of the study are in conformity with the findings of Hasmukh and Lokesh (2016) and Mohan and Rameshkumar (2013).

It can be concluded that, the major constraints expressed by the head reach and tail-end farmers viz., inadequate training programmes conducted by WUCS, lack of awareness about the functions of WUCS, lack of knowledge on integrated crop management practices, obstruction to water flow from upper reach farmers, lack of adequate fund from Govt. to improve irrigation structure and groupism and political interference. Therefore the important suggestions expressed by the farmers like to conduct adequate training programmes on water management followed by create awareness on the functions of WUCS, to provide information on integrated crop management practices and sanction adequate fund from Govt. to improve irrigation structure and equal importance to be given to all members of the WUCS.

\section{References}

Anand, S. K., Srinivas, A. and Raju, M. S., 1998, Constraints faced by farmers in adoption of water management technologies in Sri Ram Sagar Project Command area. Maharashtra. J. Extn. Edu., 14: 352-354.

Anonymous, 2017, Irrigated agriculture development under drought and water scarcity, International Commission on Irrigation and Drainage (ICID.CIID).

Dabhi, R. A., Soni, N. V. and Patel, J. K., 2010, Problems Faced By The 
Members Of Participatory Irrigation Management Society. Guj. J. Extn. Edu, 103-106.

Dhillon, D. S. and HANSRA, B. S., 1995, People's Participation in Rural Development Programmes, Kurukshethra, 43 (4): 7-9.

Golyanaik, R., 2008, People's participation in watershed development programme and its impact. Ph.D. Thesis (Unpub.), Univ. Agric. Sci. Bangalore.

Gumaste, A. K., Patil, H. N. and Nirban, A. J., 1993, Constraints in utilisation of water under minor irrigation projects in Konkan. Maharashtra. J. of Extn. Educ, 12: 373-375.

Hasmukh, P. D. and LOKESH, J., 2016, Study of Participatory Irrigation Management (PIM) system and its impact on Sustainable development of Tribal Community, (A case of Ver Medium Irrigation Project in Mandvi Taluka of Surat District in South Gujarat),
Knowledge Consortium of Gujarat $(K C G)$-portal.

Mohan, K. and Rameshkumar, P. R., 2013, Farmers' suggestions for Better Participatory Management of Tank Irrigation System. J. Res. ANGRAU41 (3) $97-99$.

Mohite, S. M., Ankush, G. S. and Nandapurkar, G. G., 1992, Constraints in the use of canal irrigation water. Maharashtra J. ExtnEdu, 11: 263-267.

SHAH, A, C., 2001, The Deprived in a Command Area of an Irrigation System, Development Support Centre, Ahmedabad.

Singh, J. P., 2000, Economic Evaluation of Manchal Watershed. Manage, Rajendranagar, Hyderabad.

Umamaheshwara, M. S., 2009, A study on community participation in irrigation tank management in Haveri district. Ph.D. Thesis (Unpub.), Univ. Agric. Sci. Dharwad.

\section{How to cite this article:}

Akkamahadevi Naik and Shivamurthy, M. 2019. Constraints and Suggestions Expressed by Head Reach and Tail-End Farmers for Participation in Effective Canal Irrigation Management. Int.J.Curr.Microbiol.App.Sci. 8(11): 1227-1237. doi: https://doi.org/10.20546/ijcmas.2019.811.144 